\title{
Consumers' Willingness to Pay for Halal Labelled Chicken Meat
}

\author{
Wilda Rizkilia Putri, Muh Samsudin, Edy Rianto, Indah Susilowati $\bowtie$
}

Faculty of Economics and Business, Diponegoro University, Semarang, Indonesia

Info Article

History Article:

Received Desembar 2016

Approved Januari 2017

Published Maret 2017

\section{Keywords:}

Consumer; Contingent Valuation Halal; Label; Willingness-to-Pay

\begin{abstract}
This research aims to analyze the level of the society's awareness of halal-certified chicken meat, and estimates the values of society's willingness to pay for halal-certified chicken meat. There are 102 female married moslem respondents in Pedurungan sub-district, Semarang, who were selected using accidental sampling. This study uses several independent variables namely income, education, age, chicken meat consumption, awareness of the importance of halal-certified products, and number of family members. The dependent variable in this research is value of respondent's willingness to pay. The results of observations was tested using the regression model of ordinary least square. The results of the analysis showed that 96 out of 102 respondents stated that they were willing to pay for certified halal meat at a range of $\mathrm{Rp} 36,500.00$ to Rp 39,000.00 per kilogram. The variables that influenced respondents' willingness to pay were: income, education, consumption of chicken meat, halal awareness of products, and number of dependent family. Those variables influenced consumer's willingness to pay positively and significantly. Meanwhile, the variable age affected significantly at a negative direction.
\end{abstract}

\section{Kemauan Bayar Konsumen atas Daging Ayam Ras Bersertifikat Halal}

\begin{abstract}
Abstrak
Riset ini bertujuan untuk menganalisis tingkat kesadaran masyarakat akan daging ayam bersertifikat halal, dan mengestimasi nilai kemauan bayar masyarakat atas daging ayam bersertifikat halal. Penelitian ini menggunakan 102 responden wanita muslim yang berumah tangga di Kecamatan Pedurungan, Kota Semarang. Responden ini dipilih dengan menggunakan metode accidental sampling. Penelitian ini menggunakan beberapa variable independen, yaitu: pendapatan, pendidikan, umur, konsumsi daging, kesadaran akan pentingnya sertifikasi produk halal dan jumlah anggota keluarga. Sedangkan variable dependen adalah kemauan bayar konsumen. Hasil observasi diuji dengan model regresi ordinary least square. Hasil analisis menunjukkan bahwa terdapat 96 responden dari 102 yang menyatakan bersedia membayar daging bersertifikasi halal dengan rentang harga Rp 36.500,00 per kilogram hingga Rp 39.000,00 per kilogram. Variabel yang berpengaruh terhadap kemauan bayar responden adalah: pendapatan, pendidikan, konsumsi daging ayam, kesadaran atas produk halal, dan jumlah tanggungan keluarga. Variabelvariabel teresebut berpengaruh secara positif dan signifikan terhadap kemauan bayar konsumen. Sedangkan variabel usia mempengaruhi secara signifikan dengan arah hubungan yang negatif.
\end{abstract}

JEL Classification: M3, M31 
Wilda Rizkilia Putri, et al. / Consumers' Willingness to Pay for...

\section{INTRODUCTION}

As a result of crisis in food security and the numerous number of incidents regarding foods which are unfit for consumption circulating around the community, consumers pay a greater attention to food security, quality, origin, and contents (Verbeke et al., 2013). Halal Food product has been important issue the world due to its alternative standards for security, hygiene, and quality guarantee of what people consume (Ambali \& Bakar, 2014). Halal concept has gained acceptance from both Moslem and non-Moslem (Aziz \& Chok, 2013).

Halal is anything the sharia allows for consumption. It deals mainly with food and beverage. Verbeke et al. (2013) state that Halal is a belief in the process of an attribute and as such its characteristics are invisible and intangible, making it hard to be evaluated or verified by consumers. Therefore, something capable of ensuring halalness is needed.

Halal Food product has been important issue for moslems. It is because for them the purity and halalness of something they would consume or use should absolutely be considered, since this will determine whether or not the deeds that we do will be accepted by Allah SWT later in the afterlife. On the other hand, if it is haram or not pure, our good deeds will definitely be rejected by Him, and we will also be deemed to have committed a sin (Adisasmito, 2008).

According to the Indonesian Ulema Council's Assessment Institute for Foods, Drugs and Cosmetics in MUI's fatwa No. 12 of 2009 (MUI, 2009), halal has three categories namely halal based on: (1)the substance, i.e. the type of animals and contents of food materials, (2)processing, and (3) execution (the process of slaughtering for meats,or packaging in processed products, and their distribution to consumers).

Indonesia is a country which has biggest moslem population around the world according to Future Global Moslem Population's (2011) data. Such large amount of moslem population in Indonesia can be viewed that Indonesia has great potential market for halal products. It is confirmed by a report by State of The Global Islamic Economy Report 2015/2016 which says that Indonesia is placed number one for the biggest halal food products in the world. Indonesians could spend $\$ 157$ billion or about $\mathrm{Rp}$ 2,041 trillion to buy halal foods during 2014 (Hasan, 2015).

The responsive Indonesian Government is surely getting more attentive to food security for its people. The Law Number 33 of 2014 was issued by the government as a halal product assurance regulation (Republic of Indonesia Law Number 33 of 2014). In addition to law concerning halal product assurance, the Indonesian Ulema Council established an Assessment Institute for Foods, Drugs, and Cosmetics (LPPOM MUI). Currently LPPOM MUI is an independent institution dealing with halal certification. A certification is a written fatwa from the Indonesian Ulema Council based on Islamic sharia. The marker of certification takes the form of a halal label on product package for a two-year valid period.

Recently, despite the regulations and laws of halal product assurance, many food products distributed to the society contain hazardous materials and alcohol as well as substances from pig and their derivatives. In addition, the society is currently obtaining imperfect information about the quality of meats sold in markets. They are being haunted by the distribution of meats unfit for consumption such as in the case of broiler chickens, where chicken meats containing formalin and even those indicated to have been expired or usually called tiren are still massively sold. Moslem community is also faced with the doubt they have about the way the chickens are slaughtered, i.e. whether it has been done according to Islamic sharia or not.

At least in 2014 and 2015 there was one case of tiren meat distribution in Central Java each year. On March 2014, at least 20 people of Darmakeradenen village, Ajibarang Subdistrict, Banyumas Regency, Central Java were forced to be hospitalized for being allegedly poi- 
soned with expired chicken meats or tiren (literally meaning dead yesterday). One of the customers said that they consumed meat chickens sold around their place by a local seller at a very cheap price. It was suspected that the chicken meats they ate on Wednesday night, March 4, 2014 were expired chicken meats (Ayyubi, 2014).

In 2015, another tiren meat case was found in Central Java Province, in Semarang City to be precise. A meat seller named Kusni, 50, a resident of Margosari Baru I RT 7 RW 7, Sawah Besar Village, Gayamsari Sub-district, Semarang was found selling expired chicken meats in $\mathrm{Ge}$ nuk Market, Semarang. The sales of carrion was exposed by the police officers of Criminal Detective Directorate (Reskrim) of Polrestabes of Semarang. It was explained that the culprit was deliberately distributed the chickens he bought after they were dead or they had been carrions. He collected those expired chicken meats and, then, processed them by cutting them in pieces. Afterwards, the pieces were given yellowish ingredients and sold in Genuk Market, Semarang as processed meats (Radar Semarang, 2015).

Broiler chicken meat is classified as important food materials according to BPS. Indonesians' broiler chicken meat consumption per capita has increased from 2012 to 2014 . According to BPS (2015) data in 2012 the meat chicken consumption of Indonesian people was $0.076 \mathrm{~kg}$ per capita a week and then it increased to $0.078 \mathrm{~kg}$ per capita in 2013, and in 2014 it became $0.086 \mathrm{~kg}$ per capita a week.

Broiler chicken meats have sound nutrition content. According to Fatkhi et al. (2016) broiler chicken meats have high nutrition, with nice taste and aroma, mild texture and relatively financially affordable, making them desirable by many people. The nutritions that broiler chicken meats have include $74 \%$ water, $22 \%$ protein, $1.46 \%$ fat, $13 \mathrm{mg}$ calcium, $190 \mathrm{mg}$ phosphor, 1.5 mg iron, and the restsare vitamin A, C, E, and fat (BPS, 2015).

Broiler chicken is an aves, which basically is halal to be consumed by Moslems. However, its meat becomes halal or not depending on certain requirements such as; it is not something stolen, it is slaughtered by saying Allah's name and the slaughterer is a Moslem and it is not a carrion because it is clear that other than fish and grasshopper any carrion is haram to be consumed. Furthermore, the chicken does not contain any poisonous materials that put the body in danger (Khoir, 2002)

According to Dwiatmaja and Rakhmadi (2012) tiren chicken meat is highly dangerous when it is consumed by the body. This is because tiren chicken does not undergo slaughter process, resulting in sedimented blood within it. Such sedimented blood influences the meat texture because, in principle, blood circulates through all part of a creature's body. Hence, when the blood does not circulate it will settle, causing the texture to change. This texture change is followed by an increase of $\mathrm{pH}$ inside the meat which causes the meat to deteriorate more quickly and leads bacteria to breed very fast. In tiren chicken meat there are bacteria which breed very fast namely B. subtilis, Pseudomonas, Streptococcus, and Leuconostoc. These bacteria can cause the humans consuming tiren chicken meat to be poisoned.

The respondents in this research are married women. According to Astuti (2013), a mother plays an important role in a family's life, for both her husband and children. Anirah (2010) suggests that a woman should prepare herself to perform her duties as a wife and a mother for her children, supported by her high education and vast knowledge, particularly the skills and competence in managing her harmonious household welfare on the basis of the piety to Allah SWT. Newborns know nothing about what is around them. It is at this time that a mother's role is highly important in educating and directing these kids. The first and main educators are parents.

According to Khoir (2002) knowing, finding, and consuming halal foods and drinks is a must (fardlu 'ain) for every moslem. Parents must give sustenance and foods which are halal to their children. It is a must for every moslem to select and sort only edible and halal foods and drinks to consume. 
This research is based on several previous studies such as that of Ibrahim (2011). His research aims to analyze the Willingness To Pay of moslem community in Georgia for premium quality halal mutton. Its respondents are 89 using probit model. At average, the WTP for halalcertified mutton is 50 cent per meat pound.

A study by Verbeke et al. (2013) aims to discover the value of willingness to pay of moslems in Belgium for halal-certified meat in supermarket and Islamic meat shop. The meat in the cases of this study is chicken meat. The research involves 202 moslem respondents. The results of research find that moslem customers are willing to pay halal meat higher in Islamic meat shop than in supermarket. Additionally, female customers pay more attention to the meat halalness than male customers.

Kamaruddin et al. (2012) study about respondents' willingness to pay halal food products. The research findings indicate that respondents are willing to pay halal logistics because of the demand and costs of Halal Logistics Service. The results of this study facilitate the establishment of efficient and realistic policy requirements of halal logistics in Malaysia. The variables which significantly influence the amount of WTP are variable status in household in this case mother respondents, variable household income, and variable costs. Meanwhile, the variable halalness awareness does not have significant influence.

Nuriana (2013) researches willingness to pay halal-certified Wardah cosmetic products in two sales points in Bogor. The research results show that the variables significantly influence willingness to pay additional costs of halal-certified products are education level and respondent's intensity in observing halal label on the cosmetic product package, and such variables as income level and awareness does not have significant influence on their willingness to pay halal-certified cosmetic products.

The aim of the study is to formulate the tripatit model of Academia-Indonesian Ulema Council-National Food and Drug Agency as a plan of halal and safety food guarantee management for society.
Based on the review, the variables hypothesized to determine the society's awareness of halal-certified products are monthly household income, education level, age, chicken meat consumption, halal awareness, and number of family members influences the amount of willingness to pay. How much the additional costs the society is willing to spend for halal-certified products. The objectives of this research are (1) to identify society's awareness level of the importance of halal-certified chicken meat; (2) to estimate the value of willingness to pay halalcertified chicken meat; and (3) to analyze the factors which influence consumers' willingness to pay.

One's willingness to pay in using goods and services is determined by economic valuation method. According to Fauzi (2004) economic valuation is a non-market analysis since it is based on the mechanism of monetary valuation to unmarketed goods and service products.

Consumers surplus according to Case and Fair (2007) occurs when the maximum amount consumers can pay is greater than the amount which should actually be paid to acquire goods and services.The difference in those amounts is called consumers surplus and not paid in the context of acquiring the desired goods. Producers surplus, occur when the amount received by producers is greater than the amount which should be spent to produce a goods and service.

\section{METHOD}

The population in this research is all women embracing Islam as their religion who are married and domiciled in the research location. Since the number of population is relatively dynamic in the research area, then, the method taken is non-random sampling with a number approaching to big sample $(\mathrm{n}=100)$. The research area is selected because it is the most Moslem-populated location in Semarang City. As per the data obtained from Central Statistic Agency of Semarang City, Pedurungan Subdistrict is the most Moslem-populated area.It is recorded in BPS (2015) data in Kota Semarang 
dalam Angka Tahun 2014 that the population embracing Islam as their religion in Pedurungan Sub-district is 146,449 , followed by Semarang Barat Sub-district at 124,659 and Ngaliyan Subdistrict at 110,636.

This study uses several independent variables namely income, education, age, chicken meat consumption, awareness of the importance of halal-certified products, and number of family members. The dependent variable in this research is value of respondent's willingness to pay. This Table 1 explains the operating definition of dependent nd independent variables in the research.

Those variables are taken based on previous studies which serve as references in this research. The research uses the regression estimation technique of Ordinary Least Square (OLS) or multiple linear regression. OLS technique is used to test two or more independent variables (explanatory) against one dependent variable (Greene, 2012). The OLS regression equation model used in this research is as follows:

$$
\begin{aligned}
\mathrm{WTP}= & \beta_{0}+\beta_{1} \mathrm{INCOME}+\beta_{2} \mathrm{EDU} \\
& +\beta_{3} \mathrm{AGE}+\beta_{4} \mathrm{CONS}+ \\
& \beta_{5} \mathrm{AWARENESS}+\beta_{6} \mathrm{FAM}+\mathrm{e}
\end{aligned}
$$

\section{RESULT AND DISCUSSION}

The location which was appointed for the empirical study in this research is in Pedurungan district. It was one of the districts which is located in Semarang city. The total area of the district is $526,33 \mathrm{Ha}$.

Based on Census of 2011, the total population stood at 178.544 , comprises of 88.183 men and 90.361 women. The research location was determined by several reasons such as; in accordance to the census, Pedurungan is the most populated district in Semarang city. This district also owns the largest Moslem population, in compare to other districts in Semarang, with 146.449 people in total.

Respondent characterization is needed in this research due to the vary of characteristic of the respondents. Information regarding charac-

\begin{tabular}{|c|c|c|}
\hline Variable & Definition & Remark \\
\hline WTP & $\begin{array}{l}\text { Consumer's willingness to pay halal-certi- } \\
\text { fied broiler chicken meat. }\end{array}$ & $\begin{array}{l}\text { Average willigness to pay } \\
\mathrm{Rp} 36,500.00 / \mathrm{kg} \\
\mathrm{Rp} 37,500.00 / \mathrm{kg} \\
\mathrm{Rp} 39,000.00 / \mathrm{kg}\end{array}$ \\
\hline INCOME & $\begin{array}{l}\text { Respondent's household income from } \\
\text { both main and other occupations. }\end{array}$ & Rupiah (metric scale) \\
\hline EDU & $\begin{array}{l}\text { Respondent's education level ranging } \\
\text { from elementary to higher education. }\end{array}$ & $\begin{array}{l}\text { Number of schooling years (metric } \\
\text { scale) }\end{array}$ \\
\hline AGE & $\begin{array}{l}\text { Respondent's lifetime since they were } \\
\text { born until the research is conducted. It is } \\
\text { counted from the last birthday using ID } \\
\text { Card. }\end{array}$ & Year (metric scale) \\
\hline CONS & $\begin{array}{l}\text { Chicken meat consumption in a house- } \\
\text { hold in a month }\end{array}$ & $\begin{array}{l}\text { Amount of consumption per month } \\
\text { (metric scale) }\end{array}$ \\
\hline AWARENESS & $\begin{array}{l}\text { How many statements about broiler } \\
\text { chicken meat which can be said halal are } \\
\text { responded to by a respondent. }\end{array}$ & Awareness Intensity (metric scale) \\
\hline FAM & $\begin{array}{l}\text { Number of family members living togeth- } \\
\text { er, sharing the kitchen in each household. }\end{array}$ & Numeric variable \\
\hline
\end{tabular}
teristic of the respondents was obtained from

Table 1. Operating Definition of Research Variables 
Wilda Rizkilia Putri, et al. / Consumers' Willingness to Pay for...

the distributed questionnaire. The questionnaire was designed to accommodate characteristics of each respondents.
Interview was conducted to 102 of married women. Along with this step, samples were taken in each sub-districts in this location. Pro-

Table 2. Respondent's Socio-econoomic Characteristics

\begin{tabular}{|c|c|c|c|c|}
\hline \multicolumn{2}{|c|}{ Description } & \multirow{2}{*}{$\begin{array}{l}\text { Freq } \\
10\end{array}$} & \multirow{2}{*}{$\begin{array}{c}\% \\
10 \%\end{array}$} & \multirow{2}{*}{$\begin{array}{r}\text { Remark } \\
\text { Max: } 67\end{array}$} \\
\hline Age & $23-30$ & & & \\
\hline & $31-37$ & 6 & $6 \%$ & Min: 23 \\
\hline & $38-44$ & 11 & $11 \%$ & Mean: 47 \\
\hline & $45-51$ & 46 & $45 \%$ & \\
\hline & $52-58$ & 25 & $25 \%$ & \\
\hline & $>59$ & 4 & $4 \%$ & \\
\hline \multirow[t]{2}{*}{ Marital Status } & Married & 96 & $94 \%$ & \\
\hline & Widow & 6 & $6 \%$ & \\
\hline \multirow[t]{7}{*}{ Education Level } & Elementary Graduate & 4 & $4 \%$ & Max: 18 \\
\hline & Junior High Graduate & 5 & $5 \%$ & Min: 6 \\
\hline & Senior High Graduate & 30 & $29 \%$ & Mean: 14 \\
\hline & D3 & 15 & $15 \%$ & \\
\hline & S1 & 40 & $39 \%$ & \\
\hline & $\mathrm{S} 2$ & 8 & $8 \%$ & \\
\hline & S3 & 0 & $0 \%$ & \\
\hline \multirow[t]{13}{*}{ Income (rupiah) } & Rp1,000,000- & & & Max: \\
\hline & $\mathrm{Rp} 2,000,000$ & 8 & $8 \%$ & \\
\hline & Rp2,100,000- & & & Rp53,000,000.00 \\
\hline & $\mathrm{Rp} 3,000,000$ & 11 & $11 \%$ & \\
\hline & Rp3,100,000- & & & Min: \\
\hline & $\mathrm{Rp} 4,000,000$ & 9 & $9 \%$ & \\
\hline & Rp4,100,000- & & & Rp1,000,000.00 \\
\hline & $\mathrm{Rp} 8,000,000$ & 34 & $33 \%$ & \\
\hline & Rp8,100,000- & & & Mean: \\
\hline & Rp9,000,000 & 10 & $10 \%$ & \\
\hline & Rp10,000,000- & & & Rp8,565,686.00 \\
\hline & $\mathrm{Rp} 15,000,000$ & 17 & $17 \%$ & \\
\hline & $>\mathrm{Rp} 16,000,000$ & 13 & $13 \%$ & \\
\hline \multirow[t]{6}{*}{ Number of family members } & 2 & 16 & $16 \%$ & Max: 7 \\
\hline & 3 & 40 & $39 \%$ & Min: 2 \\
\hline & 4 & 24 & $19 \%$ & Mean: 4 \\
\hline & 5 & 17 & $17 \%$ & \\
\hline & 6 & 8 & $8 \%$ & \\
\hline & 7 & 2 & $2 \%$ & \\
\hline \multirow[t]{6}{*}{ Occupational Group } & Housewife & 33 & $32 \%$ & \\
\hline & Civil Servant & 23 & $23 \%$ & \\
\hline & Private Employee & 20 & $20 \%$ & \\
\hline & Self-Employed & 20 & $20 \%$ & \\
\hline & Pensioner & 1 & $1 \%$ & \\
\hline & Other & 5 & $5 \%$ & \\
\hline
\end{tabular}


portional sampling method was used to determine samples in each sub-districts. On the other hand, to meet the number of respondents needed in this research, accidental sampling method is used.

Respondent profile in this research is differentiated based on age, marital status, respondent's education level, household income in a month, number of family members in a kitchen and respondent's occupational group. Table 2 below summarizes respondent's socioeconoomic characteristics.

In this research, the analysis performed using Contingent Valuation Method (CVM) which is employed to discover the value of respondent's willingness to pay halal-certified chicken meat. The value of consumer's willingness to pay is analyzed using CVM approach. The phases done are as follows (Karnowahadi et al., 2016): making hypothetic market, making an offer or bidding, expecting average value of willingness to pay, analysis of ols regression.

In making hypothetic market, a literature study and field observation are performed. A hypothetic situation is depicted by the absence of guarantee that the broiler chicken meat distributed around the society is halal. The distribution of chicken meats infused with formalin, dye, and slaughtered without using Islamic sharia has concerned moslem consumers.

Therefore, the government through LPPOM MUI make an effort for protection in the form of halal certification and labelling to prevent producers from cheating which may harm moslem consumers. Producers are assumed to have performed halal certification for the slaughter house they own. Broiler chicken me- ats are sold to consumers with a halal guarantee in terms of meat acquisition process, slaughter, packaging, and distribution until they reach the consumers.

The bid of value of WTP is obtained through interview with respondents using questionnaire as the aid. CVM method used in the research is bidding game. The bidding game method is done by offering gradually several amounts as a scenario choice of the chicken meat products to which certification and special treatment by considering the product hygiene are applied.

There are three bid values being offerred to respondents, they are $\mathrm{Rp} 36,500.00$ per kilogram as the first bid, Rp 37,500 per kilogram as the second bid, and Rp 39,000.00 per kilogram as the highest bid. In the first scenario, the chicken meat is certified by halal certification, non-toxic, and safe to be consumed. The durability period on room temperature ranges between 4 to 6 hours. The second scenario has the first scenario involved, in addition, the chicken has been cut, packed, and labeled by the date of slaughter, along with numbered halal certificate. The material used for the package was PE Plastics which is pressed by hand sealer machine at the tip of it. This method is used for maintaining the hygiene of the product. The durability period at room temperature is one day.

The third scenario has the first scenario involved, packaged and labeled with the date of slaughter and labeled with halal and numbered certificate. The material used for the packaging is from vacuum plastic. The chicken will be packed in the air-tight packaging. Beside the hygiene purpose, the usage of vacuum packaging

Table 4. Distribution of Values of Respondent's Willingness to Pay

\begin{tabular}{|c|c|c|c|c|}
\hline No & $\begin{array}{c}\text { WTP } \\
\text { (a) }\end{array}$ & $\begin{array}{c}\text { Respondent } \\
\text { (Person) } \\
(\text { b) }\end{array}$ & $\begin{array}{l}\% \\
\text { (c) }\end{array}$ & $\begin{array}{c}\text { WTP x Respondents } \\
\text { Willing to Pay } \\
(\mathbf{a} \times \mathbf{b})\end{array}$ \\
\hline 1 & $\mathrm{Rp} 36,500.00 / \mathrm{kg}$ & 28 & $29.17 \%$ & $\mathrm{Rp} \quad 1,022,000.00$ \\
\hline 2 & $\mathrm{Rp} 37,500.00 / \mathrm{kg}$ & 52 & $54.17 \%$ & $\mathrm{Rp} \quad 1,950,000.00$ \\
\hline 3 & $\mathrm{Rp} 39,000.00 / \mathrm{kg}$ & 16 & $16.67 \%$ & $\mathrm{Rp} \quad 624,000.00$ \\
\hline Total & & 96 & $100 \%$ & $\mathrm{Rp} 3,596,000.00$ \\
\hline
\end{tabular}


Wilda Rizkilia Putri, et al. / Consumers' Willingness to Pay for...

also intended to prolong product durability, as well as to put off the bacterial growth. The durability on room temperature is in two to three days

The respondent's average Expected Willingness To Pay (EWTP) is calculated based on data regarding respondent's distribution using EWTP formula. The classes of respondent's willingness to pay are obtained by determining first the smallest to biggest values of willingness to pay offerred by respondents. The distribution of values of respondent's willingness to pay is elaborated in the following Table 4. Based on Table 4, the value of average expected willingness to pay is obtained using the formula:

$$
\operatorname{EWTP}=\frac{\sum_{i=n}^{n} w i}{n}
$$

Where

EWTP : Average expected WTP

$W_{i} \quad$ : Value of $i$ thWTP

$n \quad:$ Number of respondents/sample

$i \quad:$ ithrespondents willing to pay

$(i=1,2,3, \ldots . . n)$

Hence, the following calculation is obtained:

$$
\mathrm{EWTP}=\frac{3596000}{90}=\mathrm{RP} 37,458.33
$$

Based on the calculation above, respondent's average expected willingness to pay of $\mathrm{Rp} 37,458.33$, which is rounded to $\mathrm{Rp}$ $37,500.00$ for its proximity reason, is obtained. The value of willingness to pay of $\mathrm{Rp} 37,500.00$ per kilogram can be used as a reference in determining halal-certified broiler chicken meet cost. Businessman can make this price as an overview if they want to sell hygienic halal-certified broiler chicken meat products by using a packagecontaining information on the slaughtering date and halal label.

The quantitative data was analysed using ordinary least square regression and the result is shown in the Table 6.

Gujarati (2014) suggests that if dw test $=$ $\left(\left(4-d_{\mathrm{u}}\right) \leq \mathrm{dw} \leq\left(4-\mathrm{d}_{\mathrm{L}}\right)\right)$ then concluded as indiscision from autocorrelation. It is found that the $\mathrm{dw}$ score was $2.283002(2.198<2.283002$ $<2.465)$. Thus, we concluded there is a positive autocorrelation in the model. After to get rid of the autocorrelation using cochrane orcutt the $\mathrm{dw}$ score became normal (1.248524).

The coefficient of determination ( $R$ square) obtained from estimation is 0.886720 . This indicates that such variables as income, duration of study (education), age, consumption, awareness, and number of family members sharing the kitchen under the same roof could explain 88.67 percent of their influence on the willingness to pay variable. The remaining 11.33 percent is explained by another variable outside the model.

Table 6. Estimation Results Dependent Variable: WTP Number of Observations: 96

\begin{tabular}{llll}
\hline Variable & Coefficient & T-Statistics & Sig. \\
\hline C & 35645.52 & 124.6103 & 0.0000 \\
INCOME & $9.03 \mathrm{E}-05$ & 15.92484 & $0.0000^{* *}$ \\
EDU & 26.36599 & 2.318701 & $0.0227^{*}$ \\
AGE & -6.787541 & -2.161238 & $0.0334^{*}$ \\
CONS & 19.33546 & 2.000750 & $0.0485^{*}$ \\
AWARENESS & 123.2829 & 5.492918 & $0.0000^{* *}$ \\
FAM & 66.98367 & 2.261473 & $0.0262^{*}$ \\
$\mathrm{R}^{2}$ & 0,886720 & & \\
F-Cal & 116,1109 & & \\
Variable Z & 7 of 7 & & \\
*significant level $0.05^{* *}$ significant level 0.01 & &
\end{tabular}


Based on the result of ANOVA test or F test an F-Cal value of 116.1109 is obtained and the F-Table value in this research is 2.37 (F-cal $>$ F-Table), thus, it can be concluded that the six independent variables namely income, duration of study, age, consumption, awareness, and number of faily members sharing the same kitchen under the same roof could simultaneously influence the willingness to pay variable which is its dependent variable.

The income variable significantly influences the amount of willingness to pay. It is found with a significance value of 0.000 where income variableis significant at probability level of 0.01 ( $p$ $<0,01)$. This result confirms the initial hypothesis which states that household income level has significant influence on the amount of willingness to pay. This research result is supported by the research by Ibrahim (2011), and Kamaruddin et al. (2012) which conclude that income significantly influence the amount of respondent's willingness to pay. The higher the household income is, the higher the amount of willingness to pay halalcertified broiler chicken meat. The high financial ability makes one capable of buying goods at the best quality he/she wants.

The education level was significantly influences the amount of respondent's willingness to pay. The education variable is 0.0227 , hence it is significant at probability level of $0.05(\mathrm{p}<$ $0.05)$. This result confirms that education level play significant influence to the amount of willingness to pay for labelled halal of chicken observed. This result is supported by the research by Nuriana (2013) that education level significantly influences willingness to pay. The higher the education level is,the higher the awareness to choose good quality and halal-certified chicken meat.

Age variable significantly influences the amount of consumer's willingness to pay too with probability significance value of 0.0334 . The income variable was also significant at probability level $0.05(\mathrm{p}<0.05)$. This result rejects the initial hypothesis which expects that age variable has not significant influence on the dependent variable. Thus, this research does not confirm the research conducted by Ibrahim
(2011) and Kamaruddin et al. (2012). According to Ibrahim (2011) and Kamaruddin et al. (2012), age is shown to have no significant influence on the amount of willingness to pay, and yet in the case of this research, the younger the respondent's age the more they want to keep their and their family's health, leading them to buy halal-certified broiler chicken meat in ordder to ensure the product hygiene.

The variable of broiler chicken meat consumption in this research does not significantly influence the amount of willingness to pay. The significance value of level of broiler chicken meat consumption is 0.0485 ( $\mathrm{p}>0.10$ ). Thus, it confirms the initial hypothesis that the amount of broiler chicken meat consumption may significantly influence the aount of willingness to pay. Hence, it confirms the research by Ibrahim (2011).

The variable of awareness of the importance of halal certified products significantly influences the amount of consumer's willingness to pay. It is found with a significance value of 0.000 where the awareness variableis significant at probability level $0.01(\mathrm{p}<0.01)$. This result rejects the initial hypothesis which expects that the variable of awareness of the importance of halal certified productsis a variable which does not have significant influence on the dependent variable. Thus, this research rejects the research conducted by Kamaruddin et al. (2012). In this research it is found that better awareness will make consumers want to pay higher for halalcertified broiler chicken meat products.

The variable of number of family members significantly influences the consumer's willingness to pay. The significance value of this variable is 0.0262 , which is significant at probability levelof 0.05 . It is also supported by Ibrahim's (2011) research and confirms the initial hypothesis of this research. The more nummber of family members under the same roof, the more people whose food security need to be protected. Therefore, paying more for halal-certified broiler chicken meatsis not a problem for the sake of their family health and security. 
Wilda Rizkilia Putri, et al. / Consumers' Willingness to Pay for...

The Role Of Academician, Government, Enterprenaur, And Communities in Chicken Meat Distribution.

Academician

They play an important role in the surveillance for halal labelled chicken distribution in public. They used to act independently from mouth-to-mouth and/ or using social- or ICTmedia. Ones of academician said that there is no 'partnership' with any other party in campaigning the halal labelled food. They used to deliver halal information by using a slogan of ASUH' which stand for 'Aman' (Safe), 'Sehat' (Healthy), 'Utuh' (Complete) and Halal”. At this time, it is hard to ensure the distribution of chicken meat in the market for halal guarantee. Unless the product have to be labelled for halal chicken to help consumers avoid from the non-edible chicken distribution.

The government owns several institutions in supervising the distribution of halal foods, especially chicken, such as Animal Husbandry Department, The Agency of Foods, Drugs and Cosmetics Supervision - Council of Ulama (LPPOM MUI) and other institutions.

Nevertheless, the supervision from institutions seems overlapping with each other, thus, it brings a lack of supervision. It is confirmed by Sri Kismiati, the lecturer from Animal Husbandry Faculty, during her interview. Many people who interviewed expressed their insight as follows: "I wondered that many obstacles in delivering halal chicken to the consumers, in fact Indonesia is a big moeslem country". It is suggested that the government should be a good facilitator to ensure the chicken products distributed in the market are fulfill the halal criteria. One of the strategy should be outlined is through patnerships among the Tripatriate parties of Government- MUI-producers of chicken products.

Indonesian people are supposed to learn one's lesson. They must been given a tough lesson for not selling meats un-fit for consumption. At this moment, the halal-watch institutions seem have not completed their function fully. Many of them are overlapping in job-descripti- on and/or fuction. Furthermore, the publication that they issued are often not accessible by the related parties. For instance, in the case of there is a publication about the list of stores selling meat which is unfit for consumption, the information of which is merely spread throughout students and internet-connected people.

Furthermore, many academicians also pointed out that there is an urgency of raising the awareness of being choosy in family-food consumption. It is absolute that health takes money.

\section{Government}

To explore the standpoint of the government, indepth interview was employed; meeting Head of Department of Animal Husbandry and Veterinary (Dinakkeswan), Agus Waryanto on 26th October 2016. The role of Dinakkeswan in maintaining the distribution of broiler is by doing a regular surveillance cooperated with local government of Economic and Trade Department, of Fisheries Department, Technical Service Unit (UPTD), and other municipal offices. The transcript explaining the role of Dinakkeswan:

"Our role is doing surveillance on the distribution of form formaldehyde-contaminated meat and any form of meat unfit for consumption. We are coherently working with municipal offices of Industry and Trade Service (Desperindag), Fisheries, UPTD, and any other stakeholders. It is a compulsory act to reduce the using of formaldehyde." Dinakkeswan regularly patrols around markets; additionally, it facilitates Assessment Institute for Foods, Drugs, And Cosmetics by Indonesian Council of Ulama (LPPOM MUI) in doing halal certified slaughter system.

"When it comes to helping LPPOM MUI in doing training for halal-certified food, we (Dinakkeswan) only responsible only for the event. In such an opportunity, an overnight training regarding halal slaughter was held in a guesthouse provided by Dinakkeswan. Eventually, a certificate from MUI and municipal government was given for slaughterer." 
Currently, Dinakkeswan of Central Java Province are working on Veterinary Health Center (Puskewan) in 35 municipalities. According to Pak Agus, the existence of Puskewan has an intention as to expand the health service for animals. Puskewan is expected to be a platform where in farmers may go consult, thereof the mortality rate of livestock might decrease. "The establishment of Puskewan is expected to minimize mortality rate of livestock, particularly broiler. Broilers are very dangerous for health and not halal if it is sold in died condition".

\section{Entrepreneur}

Currently, businessmen have a major role in the distribution of broilers. According to indepth interview with the key person of RPA (slaughterhouse) Waluyo, Bapak Sutar; the awareness in sustaining the quality of broilers has been on the satisfatory level. Businessmen manifested their awareness by registering their chicken slaughterhouse to LPPOM MUI in order to obtain RPA-Halal Certificate. "In the case of RPA, the registration has been done since 2007 which is quite long time ago. We have been aware of public trust regarding halal product which is free of formaldehyde and has not been expired."

Bukhori, a butcher posited, "I have not registered to MUI yet, however, I have registered myself for training for halal slaughtery which is provided by MUI and Dinakkeswan. So, it is apparent that 'insyaAllah' (if God wills) I do understand the rules that I am not supposed to sell expired chicken nor preserved chicken.”

\section{Community}

Furthermore, these days LPPOM MUI has provided socialization roadshow to broiler businessmen. For the time being, LPPOM MUI merely issues the permit to slaughter halal-certified livestock. The requirements include the obligation to only give the slaughter rights for those who are Moslem, has a sensible mind, and emotionally mature (baligh). Additionally, the livestock are supposed to be in fit condition as not to be hurt by smacking nor overfeeding of water. As claimed by the secretary of LPPOM MUI Drs. Ir. H. Mohammad Iman, MBA.

"For this moment, LPPOM only provide butcher with permit via slaughterhouse. To provide those who are willing to register for halalcertified RPH and RPA, we will take a survey and score on slaughter process. Later on, a Fatwa Commission Meeting (Sidang Komisi Fatwa) will be held to determine the issuance of halalcertified RPH and RPA" As the matter of fact, the high awareness of people regarding halal-certified chicken could be a very good input for businessmen. Poeple demand the halal-certified because it guarantees the freshness, the genuineness of its substance, and the halal process.

\section{CONCLUSION AND RECOMMENDATION}

Based on the research results, a conclusion can be made that 96 respondents out of 102 female married moslem respondents agree to pay halal-certified broiler chicken meat. On average, respondents are willing to pay halalcertified broiler chicken meat at Rp 37,500.00 per kilogram. The result of OLS regression indicated that the variables which influence respondent's willingness to pay were: income, education, chicken meat consumption, awareness of halal product, and number of family dependants. Those variables have positive and significant influence on consumer's willingness to pay. Meanwhile, the age variable has significant influence at negative direction.

In line with the results of this study, it is expected that relevant parties give more attention the distribution of broiler chicken meats. Currently, people tend to concern about hygienic and halal-labelled package. In the future, producers could perform halal certification for chicken slaughter house they own and have a standardized packaging for their broiler chicken meats. The government which plays an important role as a regulator should also consider halal-certified broiler chicken meat price to prevent it from going too high to enable all, rather than just the middle-up classes, of the society to benefit from it. For further studies, it is expected 
Wilda Rizkilia Putri, et al. / Consumers' Willingness to Pay for...

that they could examine deeper the research population calculation and expore in detail the roles of relevant parties in managing food security.

\section{Acknowledgement}

This paper was funded from MP3EI research scheme FY 2015/2016 by the Directorate of Research and Social Services, Ministry of Research, Technology and Higher Degree, Republic of Indonesia. Our appreciation goes to Prof. H. Ahmad Rofiq, the secretary of Indonesian Ulema Council of Central Java Province for his useful thought for halal concept. Thanks to students of Prof. Indah Susilowati in Diponegoro Universityas the enumerators. Great thanks to the anonymous reviewer who provides constructive inputs for this paper.

\section{REFERENCES}

Adisasmito, W. 2008. Analisis Kebijakan Nasional MUI dan BPOM dalam Labeling Obat dan Makanan. Jurnal Kebijakan Nasional MUI dan BPOM Fakultas Kesehatan Masyarakat Universitas Indonesia.

Ambali, A. R \& Bakar, A. N. 2014. People's Awareness on Halal Foods and Products: Potential Issues for Policy-Makers. Procedia - Social and Behavioral Sciences. 121: 3-25.

Anirah, A. 2010. The roles of Mothers in the Development of Islamic Educationin Familial Environment. Musawa. 2: 11-24.

Astuti, A.W.W. 2013. The Roles of Housewives in Familial prosperity improvement. Thesis. Universitas Negeri Semarang.

Ayyubi, S. 2014. 20 people are poisoned by Tiren Chicken in Banyumas. available at:http:// daerah.sindonews.com. 23 August 2016).

Aziz, Y. A \& Chok, N. V. 2013. The Role of Halal Awareness, Halal Certification, and Marketing Components in Determining Halal Purchase Intention Among Non-Muslims in Malaysia: A Structural Equation Modeling Approach. Journal of International Food \& Agribusiness Marketing. 25 (1): 1-23.

BPS. 2015. List of Important Food Materials of 20072014. https://www.bps.go.id/Subjek/view/ id/24\#subjekViewTab3|accordion-daftarsubjek3. 23 August 2016.

BPS. 2015. Semarang City in Figures of 2014. Sema- rang: Center for Statistics Bureau of Semarang City and BAPPEDA of Semarang City.

Case, K.E \& Fair, R.C. 2007. Economic Principles 8th ed. Jakarta: Erlangga.

Dwiatmaja, A.W \& Rakhmadi, F.A. 2012. Characteristics of Tiren Chicken Meat's and Normal Chicken meat's Resistance. Prosiding Pertemuan Ilmiah XXVI HFI Jateng \& DIY. 218-222.

Fathi, E., Zailani, S., Iranmanesh, M \& Kanapathy, K. 2016. Drivers of consumers' willingness to pay for halal logistics. British Food Journal. 118 (2):464-479.

Fauzi, A. 2004. Natural Resource and Environmental Economy. Jakarta: PT. Gramedia Pustaka Utama.

Greene, W. H. 2012. Econometric Analysis International Edition. 7th ed. New Jersey: PearsonPrentice Hall.

Gujarati, D. N. 2014. Basic Econometrics. 4th ed. New York: McGraw-Hill.

Hasan, S. 2015. State of The Global Islamic Economy Report 2015/16.

Ibrahim, M. 2011. Consumer Willingness to Pay a Premium for Halal Goat Meat: A Case from Atlanta Georgia. Journal of Food Distribution Research. 72-76.

Kamaruddin, R., Iberahim, H \& Shabudin, A. 2012. Willingness to Pay for Halal Logistics : The lifestyle choice. 50 (July):722-729.

Karnowahadi., Susilowati, I \& Purbayu B. S. 2016. Willingness to Pay Pelestarian Heritage Di Kota Surakarta. Semarang: Universitas Diponegoro.

Khoir, M. 2002. Risalatul Hayawan. Kediri: Duta Karya Mandiri.

MUI. 2009. Fatwa ofIndonesian Ulema Assembly No. 12 of 2009.

Nuriana, W.D. 2013. Analisis Willingness to Pay on Halal Certification on Cosmetic Products of Wardah onTwoSelling Locations in Bogor. Bogor: Agricultural Institute of Bogor.

Republic of Indonesia Law Number 33 of 2014: Halal Product Guarantee.

Radar Semarang, 2015. Tiren Chicken Openly Sold in Genuk Market. Radar Semarang, p.http:// www.radarsemarang.com/20150715/ayamtiren-b. 23 August 2016).

Verbeke, W., Rutsaert, P., Bonne, K., \& Vermeir, I. 2013. Credence quality coordination and consumers' willingness-to-pay for certified halal labelled meat. Meat Science. 95 (4): 790-797. 